\title{
A narrative review about challenges in peri- and postnatal management of gastroschisis
}

\author{
Anca Angela SIMIONESCU ${ }^{1,2}$, Bianca Mihaela DANCIU ${ }^{3}$, Vlad DIMA ${ }^{4}$, \\ Ana Maria Alexandra STANESCU ${ }^{5}$, Dora BOGHITOIU ${ }^{6,7}$ \\ ${ }^{1}$ Department of Obstetrics and Gynecology, \\ "Carol Davila" University of Medicine and Pharmacy, Bucharest, Romania \\ 2Department of Obstetrics and Gynecology, Filantropia Clinical Hospital, Bucharest, Romania \\ ${ }^{3}$ Department of Obstetrics and Gynecology, \\ "Dr. Alfred Rusescu" National Institute for Maternal and Child Health, Bucharest, Romania \\ ${ }^{4}$ Department of Neonatology, Filantropia Clinical Hospital, Bucharest, Romania \\ ${ }^{5}$ Department of Family Medicine, "Carol Davila" University of Medicine and Pharmacy, Bucharest, Romania \\ "Grigore Alexandrescu" Emergency Clinic Hospital for Children, Bucharest, Romania \\ 7"Carol Davila" University of Medicine and Pharmacy, Bucharest, Romania
}

\begin{abstract}
Gastroschisis is a malformation of the closure of the anterior abdominal wall which has had a growing incidence in recent years. It is a borderline pathology between several specialties such as: obstetrics, neonatology, pediatric surgery, family medicine and requires many resources. In general, the chance of survival of newborns with gastroschisis is high. However, complex cases with complications are more likely to have an unfavorable prognosis. The therapeutic plan should start from the intra-embryonic period, from the time of the ultrasound diagnosis and it should extend over a long period of time, which can vary depending on the case, and on the surgical options. When it comes to the management of the cases, there is no valid protocol for all the cases, and there is a great variability starting with the choice of birth time, birth pathway, the option of reintegrating the intestinal loops and closing the abdominal defect. Because of this, the cases of gastroschisis represent a challenge for modern medicine, when also taking into account the fact that the etiopathogenesis of this malformation is not clearly established and that there is a large variety of therapeutic options.
\end{abstract}

Keywords: gastroschisis, perinatal management, surgery of gastroschisis

\section{INTRODUCTION}

Gastroschisis is the most frequent developmental defect of the anterior abdominal wall. The prevalence is approximately 4 in 10,000 live births [1] and it has been continuously rising over the past 3 decades $[2,3]$ due to both more accurate pregnancy screening and the development of the advanced neonatal therapy which has led to a higher rate of survival for premature newborns. In terms of sex incidence, it occurs more frequently among male newborns with a male to female ratio of 3 to 1 , and even 4 to 1 in association with other malformations $[4,5]$.

Cigarette smoking during pregnancy is one of the strongest documented maternal exposure factors asso- 
ciated with increased gastroschisis occurrence [6]. There is also a well-documented relationship between young maternal age and incidence of gastroschisis, where the teenage mothers are considered to be a high-risk group [5,7].

According to a recent global multinational study [8], among gastrointestinal anomalies, mortality prognosis of gastroschisis depend on country income strata. In high-income countries, survival rates exceed 90\% [9], but the treatment used, starting from the childbirth technique, the early postnatal management, the closure technique and nutritional support requires a large amount of resources which causes this pathology to be among the most expensive in neonatal intensive care units (NICUs) $[8,10]$. The $10 \%$ morbidity is attributed to complex gastroschisis which represent the cases leading to intestinal failure. These babies have the highest risk of adverse outcome, requiring long term parenteral nutrition, mechanical ventilation and special NICU strategies and treatment $[11,12]$.

Gastroschisis was first described in the literature by Calder in 1733 [13]. It is a periumbilical abdominal wall defect that results in the herniation of abdominal structures (usually bowel, but it is also rarely associated with liver herniation) out of the abdominal cavity. The malformation is dangerous for the fetus because of the exposure of the intestinal loops to amniotic fluid in utero and the complications that might arise in the extrauterine life. The changes that may occur in the structure of the intestinal loops are caused by both the exposure to amniotic fluid, with irritating effect, but also by the compression made by the edge of the orifice on the venous and lymphatic circulation [14].

\section{EMBRYOLOGY OF GASTROSCHISIS}

The abdominal wall results from the fusion of four mesodermal folds: the cephalic one that forms the thoracic wall and the epigastric portion of the abdomen, the caudal fold that forms the perineum, the bladder and the hypogastrium and the lateral folds that form the lateral walls of the abdomen. The mesodermal folds fuse in the center, thus forming the umbilical ring which is completely formed in the fourth week of intra- uterine life. The primitive intestine has a faster growth than the abdominal cavity in the 6th week, which leads to its herniation through the umbilical ring, and then passes through the process of rotation and reintegration between the 10th and 12th weeks of intrauterine life. There are 4 possible theories for the pathogenesis of the gastroschisis: the failure of the mesoderm to form the body wall [15], an abnormal involution of the right umbilical vein leading to weakening of the anterior body wall [16], a vascular accident of the right vitelline artery which leads to infarction and necrosis of the body wall at the base of the umbilicus [17], or the rupture of amnion surrounding the umbilical ring [18].

\section{MANAGEMENT OF CASES}

The management of gastroschisis cases is a complex process, which requires a multidisciplinary team that must establish the best therapeutic plan for the particularities of each case. Starting with the diagnosis, which should be made as early as possible, and continuing with the follow-up of the pregnancy and the evolution of the malformation, the perinatal time, the choice of therapeutic option and the post-interventional follow-up, these are all steps that need to be taken according to protocols, case variability and maternal consent.

\section{Prenatal diagnosis}

Nowadays, gastroschisis is usually diagnosed on prenatal ultrasonography in the first trimester of pregnancy [19].

While herniated intestinal loops lacking a covering membrane can be visualized by prenatal ultrasonography, the accurate prognosis of these fetuses still remains challenging. The herniated intestinal loops floating in the amniotic fluid, intra or extra-abdominal bowel dilation [20], polyhydramnios [1] are ultrasonographic signs of gastroschisis. The main differential diagnosis is the omphalocele (table 1 ).

A recent study of 34 cases of gastroschisis showed a positive predictive value of $100 \%$ for predicting simple gastroschisis for a cut-off value of $18 \mathrm{~mm}$ for intraab-

TABLE 1. Comparison in terms of ultrasonography between gastroschisis and omphalocele [21,22]

\begin{tabular}{|l|l|l|}
\hline & Gastroschisis & Omphalocele \\
\hline $\begin{array}{l}\text { Covering by the } \\
\text { amniotic membrane }\end{array}$ & No membranous covering & $\begin{array}{l}\text { Presence of the covering amniotic membrane. If the sac is } \\
\text { ruptured, it may look like gastroschisis but with remnant } \\
\text { omphalocele sac and abnormal umbilical cord }\end{array}$ \\
\hline $\begin{array}{l}\text { Presence of other } \\
\text { herniated organs }\end{array}$ & Usually no other solid organ herniated & $\begin{array}{l}\text { More frequently associated with the presence of solid } \\
\text { organs like: liver, spleen, sometimes gonads }\end{array}$ \\
\hline Location & $\begin{array}{l}\text { Paraumbilical, most often on the right } \\
\text { umb of cases are located on the left side of the } \\
\text { umbilicus (same associated abnormalities, } \\
\text { complications and survival rate) [23] }\end{array}$ & $\begin{array}{l}\text { Within the insertion of the umbilical cord into the } \\
\text { abdominal wall }\end{array}$ \\
\hline
\end{tabular}


dominal bowel dilatation [23]. McNelis et al. has founded a different body composition of intrauterine growth restricted fetus with gastroschisis associated with the prediction of the neurologic outcome [24].

\section{Perinatal management}

Cases of gastroschisis should be considered by a multidisciplinary team consisting of at least: an obstetrician, a neonatologist, and a pediatric surgeon.

When it comes to the delivery, this should take place at a tertiary care center with a NICU and a pediatric surgery team if possible. Otherwise, the risk of complications increases significantly [25].

The timing of birth is an intensely debated subject, due to the fact that it is necessary to balance the need for the fetus to stay as close as possible to term in the uterus, in order to finalize the development, and the negative effects of amniotic fluid on the intestinal loops, for which every extra day can result in their irrecoverable damage. Because of this, elective preterm delivery can lead to well-established prematurity related complications, such as respiratory distress syndrome, while the long term exposure of the bowel to amniotic fluid cand lead to necrosis, atresia or necrotizing enterocolitis.

TABLE 2. Studies regarding the most appropriate time of delivery

\begin{tabular}{|l|l|}
\hline Study & $\begin{array}{l}\text { Conclusions regarding delivery time and } \\
\text { method }\end{array}$ \\
\hline $\begin{array}{l}\text { Mesas Burgos } \\
\text { et al. [26] }\end{array}$ & $\begin{array}{l}\text { Planned cesarean delivery at 35 weeks is } \\
\text { recommended }\end{array}$ \\
\hline $\begin{array}{l}\text { Overcash } \\
\text { et al. [27] }\end{array}$ & $\begin{array}{l}\text { No evidence to support routine induction of } \\
\text { delivery }\end{array}$ \\
\hline Baud et al.[28] & $\begin{array}{l}\text { Induced labor at 37 weeks is associated with } \\
\text { reduce risk of bowel damage, sepsis and } \\
\text { neonatal death }\end{array}$ \\
\hline Cain et al. [29] & $\begin{array}{l}\text { Delivery at 37-39 weeks is associated with } \\
\text { improved perinatal outcomes }\end{array}$ \\
\hline $\begin{array}{l}\text { Youssef et al. } \\
\text { [30] }\end{array}$ & $\begin{array}{l}\text { For every week in utero, the percent of } \\
\text { patients with severe matting (disruption } \\
\text { of the normal smooth bowel wall contour) } \\
\text { decreases by 3.6\% }\end{array}$ \\
\hline Nasr et al. [31] & $\begin{array}{l}\text { Delivery } \geq 38 \text { weeks is associated with } \\
\text { increased bowel matting }\end{array}$ \\
\hline $\begin{array}{l}\text { Carnaghan } \\
\text { et al. [32] }\end{array}$ & $\begin{array}{l}\text { Preterm delivery is detrimental to neonatal } \\
\text { gut function resulting in prolonged } \\
\text { dysfunction. The positive effect of fetal } \\
\text { bowel maturation in the latter stages of } \\
\text { pregnancy has a stronger influence on bowel } \\
\text { motility and neonatal outcomes than the } \\
\text { negative effects of prolonged amniotic fluid } \\
\text { exposure. }\end{array}$ \\
\hline
\end{tabular}

The motility pathologies occur because the maturation of the interstitial cells of Cajal take place in the later stages of the third trimester [33]. Given all of the above studies, the general recommendation, based on the available data, is the delivery at 37 weeks, while also taking into account the particularities of each case and the obstetrician indications. Regarding the delivery method, multiple studies have shown that labor and vaginal delivery have not been associated with worse outcome [34-36].

\section{Postnatal management}

At the time of birth of the newborn with gastroschisis, the NCIU team must be present and prepared to provide homeostasis, respiratory support depending on their pulmonary status, thermoregulation, and protection for the bowels. At least one vascular access pathway must be obtained, while generally avoiding umbilical vascularization and a nasogastric tube placed for gastro-intestinal decompression.

Broad-spectrum antibiotics and fluids should also be administered as soon as possible. In the first 24 hours of life, fluid losses are 2.5 times higher that normal [37].

Volume resuscitation should be performed with care, in order to treat hypovolemia, while at the same time taking into account the side effects and complications that routine bolus fluid resuscitation brings [38].

The extruded bowel must be wrapped into sterile saline dressing and an impermeable material, to minimize the fluid losses. The bowels must be handled with great care to avoid compromising their vascularity.

\section{CLOSURE OPTIONS}

These techniques depend on the state of the bowels and of course of the newborn. While the exposed viscera put the infant to an increased risk of infection and dehydration, these do not constitute a strong enough case for hastening their reintegration and the closure of the abdominal defect, in situation where this objective cannot be achieved per primam.

\section{Primary closure}

Primary reduction is the preferred method if the eviscerated contents can be safely placed into the abdominal cavity without causing excessive intraabdominal pressure. It has plenty of advantages such as: rapid placement of the intestines back into their physiological place, reduced risk of ongoing injury through exposure and mechanical irritation, lower rates of surgical site infection [39], decreased risk of vascular compromise, earlier initiation of enteral feeding [40]. It is not recommended to use primary reduction in the presence of thickened, matted, distended intestinal loops, and a small abdominal cavity, because it can lead to "abdominal compartment syndrome". This syndrome consists of lower limb vascular compromise, mesenteric ischemia and ventilatory insufficiency which are each separately life-threating complications. 
Silo placement with staged reduction and delayed closure

Suturing Teflon mesh to the defect to allow gradual reduction and delay closure of the gastroschisis was a breakthrough in the treatment of this newborns. Schuster's technique uses a transparent preformed silo with a coil spring-reinforced, deformable ring at the base, through which the bowels are introduced [41].

Initially, the method was used only in cases where the intestinal loops were too distended to be inserted into the abdominal cavity per primam. However, there are studies that have shown that the widespread use of these Teflon bags has brought superior benefits to the reintegration and suturing of the abdominal wall defect per primam [42,43].

It is also important to specify that the placement of this device does not require general anesthesia and that it can be done in NICUs.

\section{Sutureless umbilical closure}

This method is the most recent discovery in the treatment of gastroschisis. By using this technique, the viscera are reduced, and the umbilical cord is stretched across the defect and held in place without using any fascial suturing $[44,45]$.
After 2-4 weeks, the covered defect of the umbilical cord contracts all around, healing like a normal umbilicus. This technique does not require general anesthesia, and it has almost the same results with a silo [46].

\section{POSTCLOSURE MANAGEMENT}

Supportive care in the NICU continues in the post closure phase with fluids, ventilation (if necessary), sedation and analgesia and parenteral nutrition (for as long as needed).

The signs indicating that the enteral feeding can be resumed are the absence of biliary drainage from the nasogastric tube, decreased abdominal distension and the presence of stools [47].

After its reintroduction, there is frequently a temporary intolerance to food, which is not due to the defect itself but it is due to a syndrome of altered motility of the digestive tract that occurs in some cases $[48,49]$.

\section{CONCLUSION}

Gastroschisis remain a malformation with favorable outcome, even for nondiagnosed cases in prenatally period.

Conflict of interest: none declared Financial support: none declared

\section{REFERENCES}

1. O'Connell RV, Dotters-Katz SK, Kuller JA, et al.Gastroschisis: A Review of Management and Outcomes. Obstet Gynecol Surv. 2016;71(9):537-544.

2. Kirby RS, Marshall J, Tanner JP, et al.; National Birth Defects Prevention Network. Prevalence and correlates of gastroschisis in 15 states, 1995 to 2005. Obstet Gynecol. 2013;122(2 Pt 1):275-281.

3. Jones AM, Isenburg J, Salemi JL et al. Increasing Prevalence of Gastroschisis--14 States, 1995-2012. MMWR Morb Mortal Wkly Rep. 2016;65(2):23-26.

4. McGann KC, Arca MJ, Pulhamus M, et al. Left congenital diaphragmatic hernia and gastroschisis in a term male infant. BMJ Case Rep. 2021;22;14(7):e239181.

5. Castilla EE, Mastroiacovo P, Orioli IM. Gastroschisis: international epidemiology and public health perspectives. Am J Med Genet C Semin Med Genet. 2008;148C(3):162-79.

6. Skarsgard ED, Meaney C, Bassil K et al. Canadian Pediatric Surgery Network (CAPSNet). Maternal risk factors for gastroschisis in Canada. Birth Defects Res A Clin Mol Teratol. 2015;103(2):111-118.

7. Winter LW, Giuseppetti M, Breuer CK. A case report of midgut atresia and spontaneous closure of gastroschisis. Pediatr Surg Int. 2005;21(5):415-416.

8. Global Paed Surg Research Collaboration. Mortality from gastrointestinal congenital anomalies at 264 hospitals in 74 low-income, middle-income, and high-income countries: a multicentre, international, prospective cohort study. Lancet. 2021; 398(10297):325-339.

9. Bradnock TJ, Marven S, Owen A et al. Gastroschisis: one year outcomes from national cohort study. BMJ. 2011;343:d6749.

10. Haddock C, Skarsgard ED. Understanding gastroschisis and its clinical management: where are we? Expert Rev Gastroenterol Hepatol. 2018;12(4):405-415.

11. Kilby MD. The incidence of gastroschisis. BMJ. 2006;332(7536):250-251.

12. Arnold MA, Chang DC, Nabaweesi R et al. Risk stratification of 4344 patients with gastroschisis into simple and complex categories. J Pediatr Surg. 2007; 42(9):1520-1525.

13. Chabra S. Gastroschisis: brief early history. J Perinat Med. 2007;35(5):455.

14. Coran AG, Caldamone A, Adzick NS, et al. Pediatric surgery E-book (Vol. 2). Elsevier Health, 2012.
15. Duhamel JF, Coupris L, Révillon $Y$ et al. Gastroschisis: study of a series of 50 cases from 1960 to 1976 and therapeutic indications. Arch Fr Pediatr. 1979;36:40-48.

16. deVries PA. The pathogenesis of gastroschisis and omphalocele. J Pediatr Surg. 1980 Jun;15(3):245-51.

17. Hoyme HE, Higginbottom MC, Jones KL. The vascular pathogenesis of gastroschisis: intrauterine interruption of the omphalomesenteric artery. J Pediatr. 1981;98(2):228-231.

18. Shaw A. The myth of gastroschisis. J Pediatr Surg. 1975;10(2):235-244.

19. Oakes MC, Porto M, Chung JH. Advances in prenatal and perinatal diagnosis and management of gastroschisis. Semin Pediatr Surg. 2018;27(5):289-299.

20. Tassin M, Benachi A. Diagnosis of abdominal wall defects in the first trimester. Curr Opin Obstet Gynecol. 2014; 26(2):104-109.

21. D'Antonio F, Virgone C, Rizzo G, et al. Prenatal Risk Factors and Outcomes in Gastroschisis: A Meta-Analysis. Pediatrics. 2015;136(1):e159-169.

22. Goetzinger KR, Tuuli MG, Longman RE, et al. Sonographic predictors of postnatal bowel atresia in fetal gastroschisis. 
Ultrasound Obstet Gynecol. 2014; 43(4):420-425.

23. Puri P. Newborn Surgery, 3rd ed. CRC Press, 2011.

24. Nitzsche K, Fitze G, Rüdiger M, et al. Prenatal Prediction of Outcome by Fetal Gastroschisis in a Tertiary Referral Center. Diagnostics (Basel). 2020;10(8):540.

25. McNelis K, Poindexter A, Goddard G, et al. Body Composition of Infants with Congenital Gastroschisis. J Pediatr Gastroenterol Nutr. 2021 Aug 17.

26. Nasr A, Langer JC; Canadian Paediatric Surgery Network. Influence of location of delivery on outcome in neonates with gastroschisis. J Pediatr Surg. 2012;47(11):2022-2025.

27. Mesas Burgos C, Svenningsson A, Vejde $\mathrm{JH}$, et al. Outcomes in infants with prenatally diagnosed gastroschisis and planned preterm delivery. Pediatr Surg Int. 2015;31(11):1047-1053.

28. Overcash RT, DeUgarte DA, Stephenson $\mathrm{ML}$, et al. University of California Fetal Consortium. Factors associated with gastroschisis outcomes. Obstet Gynecol. 2014;124(3):551-557.

29. Baud D, Lausman A, Alfaraj MA, et al. Expectant management compared with elective delivery at 37 weeks for gastroschisis. Obstet Gynecol. 2013;121(5):990-998.

30. Cain MA, Salemi JL, Paul Tanner J, et al. Perinatal outcomes and hospital costs in gastroschisis based on gestational age at delivery. Obstet Gynecol. 2014; 124(3):543-550.

31. Youssef F, Laberge JM, Baird RJ, et al. Canadian Pediatric Surgery Network (CAPSNet). The correlation between the time spent in utero and the severity of bowel matting in newborns with gastroschisis. J Pediatr Surg. 2015;50(5):755-759.

32. Nasr A, Wayne C, Bass J, et al.; Canadian Pediatric Surgery Network. Effect of delivery approach on outcomes in fetuses with gastroschisis. J Pediatr Surg. 2013;48(11):2251-2255.

33. Carnaghan $\mathrm{H}$, Pereira $\mathrm{S}$, James $\mathrm{CP}$, et al. Is early delivery beneficial in gastroschisis? J Pediatr Surg. 2014;49(6):928-933.

34. Faussone-Pellegrini MS, Vannucchi MG, Alaggio $\mathrm{R}$ et al.Morphology of the interstitial cells of Cajal of the human ileum from foetal to neonatal life. J Cell Mol Med. 2007; 11(3):482-494.

35. Strauss RA, Balu R, Kuller JA, et al. Gastroschisis: the effect of labor and ruptured membranes on neonatal outcome. Am J Obstet Gynecol. 2003; 189(6):1672-1678.

36. Al-Kaff A, MacDonald SC, Kent N, et al.Canadian Pediatric Surgery Network. Delivery planning for pregnancies with gastroschisis: findings from a prospective national registry. Am J Obstet Gynecol. 2015;213(4):557.e1-8.

37. Segel SY, Marder SJ, Parry S, et al. Fetal abdominal wall defects and mode of delivery: a systematic review. Obstet Gynecol. 2001;98(5 Pt 1):867-873.

38. Mollitt DL, Ballantine TV, Grosfeld JL, et al. A critical assessment of fluid requirements in gastroschisis. J Pediatr Surg. 1978; 13(3):217-219.

39. Jansen LA, Safavi A, Lin Y, et al. Canadian Pediatric Surgery Network (CAPSNet). Preclosure fluid resuscitation influences outcome in gastroschisis. Am J Perinatol. 2012;29(4):307-312.

40. Baird R, Puligandla P, Skarsgard E, et al.; Canadian Pediatric Surgical Network. Infectious complications in the management of gastroschisis. Pediatr Surg Int. 2012;28(4):399-404.

41. Skarsgard ED, Claydon J, Bouchard S, et al.; Canadian Pediatric Surgical Network. Canadian Pediatric Surgical Network: a population-based pediatric surgery network and database for analyzing surgical birth defects. The first 100 cases of gastroschisis. J Pediatr Surg. 2008;43(1):30-34.

42. Schuster SR. A new method for the staged repair of large omphaloceles. Surg Gynecol Obstet. 1967;125(4):837-850.

43. Pastor AC, Phillips JD, Fenton SJ, et al. Routine use of a SILASTIC spring-loaded silo for infants with gastroschisis: a multicenter randomized controlled trial. J Pediatr Surg. 2008 Oct;43(10):1807-1812.

44. Schlatter M, Norris K, Uitvlugt N, et al. Improved outcomes in the treatment of gastroschisis using a preformed silo and delayed repair approach. J Pediatr Surg. 2003 Mar;38(3):459-64.

45. Bianchi A, Dickson AP. Elective delayed reduction and no anesthesia: 'minimal intervention management' for gastrochisis. J Pediatr Surg. 1998;33(9):1338-1340.

46. Sandler A, Lawrence J, Meehan J, et al. A "plastic" sutureless abdominal wall closure in gastroschisis. J Pediatr Surg. 2004; 39(5):738-741.

47. Emami CN, Youssef F, Baird RJ et al.; Canadian Pediatric Surgery Network (CAPSNet). A risk-stratified comparison of fascial versus flap closure techniques on the early outcomes of infants with gastroschisis. J Pediatr Surg. 2015;50(1):102-106.

48. Aljahdali A, Mohajerani N, Skarsgard ED; Canadian Pediatric Surgery Network (CAPSNet). Effect of timing of enteral feeding on outcome in gastroschisis. J Pediatr Surg. 2013;48(5):971-976.

49. Jadcherla SR, Gupta A, Stoner E, et al. Neuromotor markers of esophageal motility in feeding intolerant infants with gastroschisis. J Pediatr Gastroenterol Nutr. 2008;47(2):158-164. 